\title{
Humanitarian Intervention: Fairy TAle about One Swallow Which Made Summer?
}

\author{
Ondř̀j Svaček ${ }^{1}$ \\ Faculty of Law, Palacký University Olomouc, Czech Republic
}

ondrej.svacek@upol.cz

SVAČEK, Ondřej. Humanitarian Intervention: Fairy Tale about One Swallow Which Made Summer?. International and Comparative Law Review, 2019, vol. 19, no. 2, pp. 131-154. DOI: 10.2478/iclr-2019-0018.

\begin{abstract}
Summary: In its final report on aggression and the use of force, the International Law Association opined that the only way in which unilateral humanitarian intervention could possibly be seen as a legal exception to the prohibition of the use of force is if State practice and opinio juris were to be found establishing its status as an additional exception in customary international law. After the airstrikes conducted by the US, the UK, and France against Syria in April 2018, which took place in reaction to unprecedented usage of chemical weapons against civilian population by regime of Bashar Asad, some States and part of scholars argued that this permissive rule (exception) has already crystalized and humanitarian intervention became part of international law. The aim of this article is to assess whether these opinions are relevant or whether they are simply premature. The text is divided into three parts. Firstly, legality of humanitarian intervention is considered in the framework of the UN Charter and customary international law on the use of force based on evaluation of scholarly debates and the most prominent examples of State practice before 2018. Then, the article describes methodology that is employed in relation to the creation (modification) of customary international law in general and peremptory norm concerning the prohibition on the use of force in particular. This part analyzes how possible normative changes of jus ad bellum should be assessed. The third part evaluates justifications and reactions of States with respect to the use of force against Syria in April 2018 that were presented by the international community of States. The article concludes that the concept of humanitarian intervention remains still illegal even after the airstrikes against Syria from 2018, what conforms to the prevailing opinion presented in contemporary scholarly literature. Even though the positive echoes identified in State practice (and doctrine) are yet premature, they indicate that process of gradual normative change has already been triggered. At the same time, the expectations concerning crystallization of a new possible exception to the general prohibition on the use of force should not be too exaggerated.
\end{abstract}

1 Department of International and European Law, Faculty of Law in Olomouc, Czech Republic, member of CIHOL (https://www.pf.upol.cz/cihol), email: ondrej.svacek@upol. $\mathrm{cz}$. This text is an outcome from grant awarded by the Czech Science Foundation (reg. no. 18-25279S Use of Force in International Law with Special Focus on Focus on Visegrad Group States' Perspective).

Published by Palacký University Olomouc, Czech Republic, 2019.

ISSN (print): 1213-8770; ISSN (online): 2464-6601 
Keywords: Syria - humanitarian intervention - State practice - use of force - peremptory norms of general international law (jus cogens) - change/modification of customary international law

\section{Introduction}

In its final report on aggression and the use of force, the International Law Association (ILA) opined that the only way in which unilateral humanitarian intervention could possibly be seen as a legal exception to the prohibition of the use of force is if State practice and opinio juris were to be found establishing its status as an additional exception in customary international law (CIL). ${ }^{2}$ After the airstrikes conducted by the US, the UK, and France against Syria in April 2018, which took place in reaction to unprecedented usage of chemical weapons against civilian population by regime of Bashar Asad, some States and part of scholars argued that this permissive rule (exception) has already crystalized and humanitarian intervention became part of international law.

The aim of this article is to assess whether these opinions are relevant or whether they are simply premature. The text is divided into three parts. Firstly, legality of humanitarian intervention is considered in the framework of the UN Charter and CIL on the use of force based on evaluation of scholarly debates and the most prominent examples of State practice before 2018. Then, the article describes methodology that is employed in relation to the creation (modification) of CIL in general and peremptory norm concerning the prohibition on the use of force in particular. This part analyzes how possible normative changes of jus ad bellum should be assessed. The third part evaluates justifications and reactions of States with respect to the use of force against Syria in April 2018 that were presented by the international community of States.

The article concludes that the concept of humanitarian intervention remains still illegal even after the airstrikes against Syria from 2018, what conforms to the prevailing opinion presented in contemporary scholarly literature. Even though the positive echoes identified in State practice (and doctrine) are yet premature, they indicate that process of gradual normative change has already been triggered. At the same time, the expectations concerning crystallization of a new possible exception to the general prohibition on the use of force should not be too exaggerated.

\section{Setting the Stage - Humanitarian Intervention before 2018}

The term humanitarian intervention traditionally refers to the use of force across State borders by a State (or group of States acting together) aimed at preventing or ending a humanitarian catastrophe affecting individuals other than

2 International Law Association (ILA), Final Report on Aggression and the Use of Force, 2018, p. 21. 
its own citizens, without the permission of the State within whose territory force is applied. ${ }^{3}$

It is also necessary to distinguish unilateral humanitarian intervention and intervention under the auspices of the United Nations Security Council (UN SC). If certain humanitarian catastrophe would be classified by the SC as a threat to the peace or breach of the peace under Art 39 of the UN Charter, and if a coalition of willing States is subsequently authorized under Art 42 of the UN Charter to use force on the territory of a given State, such intervention would be in full accord with the UN Charter, which envisages centralized system of collective security. The legality of this action could not be called into question. ${ }^{4}$ Quite contrary, position of the unilateral humanitarian intervention, i.e. intervention which lacks any approval by the SC or permission of the State within whose territory force is applied, is subject to heated scholarly debates and controversies which arise once and again in connection with a new instances of serious and systematic violations of human rights and perpetration of crimes under international law. ${ }^{5}$

There is unsurprisingly huge academic clash concerning legality of humanitarian intervention. With certain simplification, these opinions can be sorted out into two categories. ${ }^{6}$ Using terminology of international relations, the opponents of lawfulness (classicists) stress very fundaments of international law, be it sovereignty and prohibition on the use of force. They argue that since humanitarian intervention is in breach of both principles, it must be prohibited. On the other hand, the proponents of lawfulness (realist) focus on shared values of humanity (especially human rights), they plead in favor of qualified legal order which would be built on human dignity. These scholars treat humanitarian intervention as a tool for protection of human rights. Both approaches find their expression in the text of the UN Charter which - from this perspective - became

3 Ibid, p. 20.

4 VÁLEK, Petr. Is Unilateral Humanitarian Intervention Compatible with the UN Charter? Michigan Journal of International Law. 2005, vol. 26, issue 4, p. 1228. Author of this article takes for granted that collective action under the auspices of the UN is a well settled exception to the general prohibition on the use of force. It disregards (rather in extremis) argument that the UN Charter, as an international treaty which is incompatible with the peremptory norm proscribing the use of force in interstate relations, should be strictly speaking considered void. $C f$. LINDERFALK, Ulf. The Effect of Jus Cogens Norms: Whoever Opened Pandora's Box, Did You Ever Think About the Consequences? European Journal of International Law. 2008, vol. 18, issue 5, p. 863.

5 In the following text, unless otherwise provided, the term humanitarian intervention is used in the sense of unilateral humanitarian intervention.

6 BARINKA, Roman. Status humanitární intervence v mezinárodním právu. [Status of Humanitarian Intervention in International Law]. Právník. 2003, vol. 142, issue 9, p. 867. The ILA describes this doctrinal schism in similar terms - cf. ILA Report, pp. 23-24. 
a hostage of mutually incompatible grammatical, historical and systematic interpretations taking side with one or the other approach. ${ }^{7}$

If the proscription or permission of humanitarian intervention cannot be unequivocally derived from the UN Charter, other sources of international law may provide a better guidance. In 1965, the UN General Assembly (UN GA) adopted the Declaration on Inadmissibility of Intervention ${ }^{8}$ which provides that "no state has the right to intervene, directly or indirectly, for any reason whatever, in the internal or external affairs of any other State. Consequently, armed intervention and all other forms of interference or attempted threats against the personality of the State or against its political, economic and cultural elements, are condemned." This declaration proscribes any type of intervention, i.e. even the intervention which would be motivated by absolutely meritorious (humanitarian) reasons. Five years later, in 1975, the UN GA adopted the Declaration on Principles of International $\mathrm{Law}^{9}$ which uses identical language. What is important, both declarations cannot be treated as mere soft law instruments. Accord-

7 It is enough to compare text of Art 1(1) and Art 1(3) or Art 2(4) and Art 55(c) of the UN Charter. One of the arguments raised by classicists refers to preparatory works of the UN Charter (Art 32 of the VCLT). They stress that the idea of humanitarian intervention was not a new one and the fact that it was not included into the text of the UN Charter must be understood as a deliberate omission. Travaux préparatoires reveal that French proposal which would (in a situation of flagrant violation of human rights) permit military intervention without the SC authorization was rejected due to its vagueness and potential for abuse. Cf. Válek, P.: supra, p. 1233. On the other side, the reference in Art 2(4) of the UN Charter to the use of force against the territorial integrity or political independence of any state has been relied upon by realists to support the use of force in circumstances that could be claimed as having other objectives (humanitarian concerns).

The concept of humanitarian intervention should not be (in the light of current state of international legal regulation) treated as a normative conflict between two rules of peremptory character. In a fact, there is no conflict here at all, or - at its best - there is only a "false conflict since the obligations that flow from the peremptory norms address different subjects of law". Cf. DE HOOGH, André. Jus Cogens and the Use of Armed Force. In: WELLER, Marc (ed.) The Oxford Handbook of the Use of Force in International Law. Oxford: OUP, 2015, p. 1185. Simply, since the obligation to prevent genocide (and other crimes under international law) on the territory of other States has not yet acquired peremptory character, it cannot be confronted with the peremptory prohibition on the use of force. Cf. VENTURA, Manuel. The Prevention of Genocide as a Jus Cogens Norm? A Formula for Lawful Humanitarian Intervention. In: JALLOH, Charles, OLUFEMI, Elias (eds.) Shielding Humanity: Essays in International Law in Honour of Judge Abdul G. Koroma. Boston/Leiden, Martinus Nijhoff Publishers, 2015, pp. 289-351. It is fair to mention that scholarly literature presents also opposing opinion and argues in favor of peremptory character of the obligation to prevent genocide. Cf. HEIECK, John. A Duty to Prevent Genocide. Due Dilligence Obligations among the P5. Edward Elgar, 2018. 264 p.

8 Declaration on Inadmissibility of Intervention in the Domestic Affairs of States and Protection of Their Independence and Sovereignty. G. A. Res. 2131, U. N. Doc. A/6014 (1965).

9 Declaration on Principles of International Law Concerning Friendly Relations and Cooperation among States in accordance with the Charter of the United Nations. G. A. Res. 2625, U. N. Doc. A/8028 (1970). 
ing to the International Court of Justice (ICJ) they reflect modern State practice and opinio juris; they codify customary international law. ${ }^{10}$

In this judgment concerning dispute between Nicaragua and the US, the ICJ further explained that no general right of intervention in support of an opposition within another State exists in contemporary international law. ${ }^{11}$ It did not lend an ear to an insistent US argument that the Nicaraguan Government had taken significant steps towards establishing a totalitarian communist dictatorship and held that it "cannot contemplate the creation of a new rule opening up a right of intervention by one State against another on the ground that the latter has opted for some particular ideology or political system." ${ }^{12}$ Of cardinal importance is the ICJ's response to an allegation concerning violation of human rights by Nicaragua: "In any event, while the United States might form its own appraisal of the situation as to respect for human rights in Nicaragua, the use of force could not be the appropriate method to monitor or ensure such respect." 13 Given this ruling, there is no other choice than to conclude that in 1980s, the concept of humanitarian intervention was clearly prohibited in international law.

This conclusion is also supported by examples of State practice after 1945, which means that it retained its validity at least until 2018. The first "precedent" concerns the action of India in the East Pakistan conducted in reaction to military repression by Pakistan against separatists in that province, which resulted in independence and proclamation of a new State - Bangladesh. India justified its intervention by exercise of its right to self-defence as at least some Pakistani attacks directed against separatists took place on the territory of India. The same holds true with respect to the invasion of Vietnam to Cambodia in 1978-1979 explained by a need to get rid of a brutal Pol Pot's Khmer Rouge regime. According to T. Franck, "Vietnam claimed to be acting in self-defense against armed border incursions by forces directed by the Khmer Rouge." ${ }^{14}$ It is hard to believe that the Vietnamese action ever had any humanitarian background given it installed the People's Republic of Kampuchea which Vietnam subsequently backed until early 1990s. The same line of reasoning (replication of self-defence argument) was used by Tanzania during its invasion to Uganda in 1978-1979.

10 Military and Paramilitary Activities in and against Nicaragua (Nicaragua v. United States of America). Merits, Judgment. I.C.J. Reports 1986, $\$ 188$ (Nicaragua v. United States). The ICJ opined that the effect of consent to the text of such resolutions cannot be understood as merely that of a "reiteration or elucidation" of the treaty commitment undertaken in the Charter.

11 Ibid, $\$ 209$.

$12 \mathrm{Ibid}, \S 263$.

$13 \mathrm{Ibid}, \S 268$.

14 FRANCK, Thomas. Interpretation and Change in the Law of Humanitarian Intervention. In: HOLZGREFE, J. L., KEOHANE, Robert (Eds.) Humanitarian Intervention: Ethical, Legal and Political Dilemmas. Cambridge, CUP 2003, p. 217. 
Situation did not change even after the ECOWAS interventions in Liberia in 1990 and Sierra Leone in 1997 to end massive atrocities during the civil wars. Here, the legal justification did not relied on humanitarian intervention but referred to the ex post facto endorsement of non-authorized unilateral action by the SC. ${ }^{15}$ Any such argumentation must be strictly denied as it goes against the plain language of Art 53 of the UN Charter which requires that mandate by the $\mathrm{SC}$ is given ex ante. ${ }^{16}$

The most discussed example of State practice in the area of humanitarian intervention before 2018 concerns the NATO action in the FRY in 1999. The UK asserted that this operation was justified as an exceptional measure to prevent an overwhelming humanitarian catastrophe. ${ }^{17}$ In the subsequent proceedings before the ICJ, most States did not try to persuade Court about legality of the raid. The only exception was Belgium, which claimed that it was acting legally under the heading of humanitarian intervention, and therefore the use of force was of a nature that did not violate Art 2(4) of the UN Charter. ${ }^{18}$ Germany stressed uniqueness of this action which must not become a precedent. ${ }^{19}$ France, Argentina, Brazil or Mexico confirmed prerogatives of the SC as a centralized and collective mechanism in the sphere of the use of force in international law. ${ }^{20}$ Generally speaking, States presented rather moral and political arguments (opinio necessitatis) and pointed out to an urgent need to safeguard protection of human rights in the situation of humanitarian catastrophe, where the SC is blocked by (implicit) veto from Russia and China.

That international law did not incorporated humanitarian intervention after the 1999 action in the FRY is persuasively demonstrated by I. Brownlie who refers to the Ministerial Declaration produced by the meeting of Foreign Ministers of the Group of 77 held in New York in September 1999, three months after the bombardment of the FRY. ${ }^{21}$ According to Brownlie, this declaration represented opinion of 132 States.

15 GOWLLAND-DEBBAS, Vera. The Limits of Unilateral Enforcement of Community Objectives in the Framework of UN Peace Maintenance. European Journal of International Law. 2000, vol. 11, issue 2, p. 375.

16 Art 53 of the UN Charter provides: "The Security Council shall, where appropriate, utilize such regional arrangements or agencies for enforcement action under its authority. But no enforcement action shall be taken under regional arrangements or by regional agencies without the authorization of the Security Council."

17 ILA Report, p. 22.

18 ICJ, Legality of Use of Force (Serbia and Montenegro $v$ Belgium), Oral Proceedings, Public Sitting (12 May 1999), p. 13.

19 SIMMA, Bruno. NATO, the UN and the Use of Force: Legal Aspects. European Journal of International Law. 1999, vol. 10, issue 1, pp. 12-13.

20 CASSESE, Antonio. A Follow - Up: A Forcible Humanitarian Countermeasures and Opinio Necessitatis. European Journal of International Law. 1999, vol. 10, issue 4, p. 795.

21 BROWNLIE, Ian. "International Law and the Use of Force by States" Revisited. Europaeum, 2001, p. 1. Paragraph 69 of this declaration reads: "The Ministers stressed the need 
Situation did not change even after the adoption of the R2P doctrine, ${ }^{22}$ this old wine in new bottles. ${ }^{23}$ Importantly, the R2P concept does not refer to the unilateral action of humanitarian concerns. It is based on a collective international responsibility to protect, exercisable by the $\mathrm{SC}$ authorizing military intervention as a last resort, in the event of genocide and other large-scale killing, ethnic cleansing or serious violations of international humanitarian law which States have proved powerless or unwilling to prevent. ${ }^{24}$ Moreover, the first pillar of the R2P accentuates the responsibility of the State where these violations of international law are occurring. ${ }^{25}$ Simply, until the emergence of crisis in Syria, humanitarian intervention was clearly considered unlawful in international law.

\section{Humanitarian Intervention in the Context of Situation in Syria}

\subsection{Positive Echoes in State Practice and Doctrine}

The crisis in Syria has become one of the most alarming challenges in the history of humanitarian intervention debates. ${ }^{26}$ Incidents of unprecedented usage of chemical weapons against civilian population revived the concept of humanitarian intervention with a new urgency.

In response to the usage of chemical agent sarin in Khan Sheikhun, on 7 April 2017, the US conducted a strike on the Syrian military base Shayrat near the city of Homs since, as the US officials claimed, the aircraft that carried out the chemical attack took off from that military base. One year later, on 14 April 2018, the US, the UK, and France conducted series of military strikes involving aircraft and ship-based missiles against multiple governmental sites in response to Douma chemical attack against civilians.

to maintain clear distinctions between humanitarian assistance and other activities of the United Nations. They rejected the so-called right of humanitarian intervention, which has no basis in the UN Charter or in international law."

22 For more information $c f$. SVAČEK, Ondřej. Dárfúr - přes humanitární intervenci $\mathrm{k}$ odpovědnosti chránit a mírovým operacím. [Darfur - From Humanitarian Intervention to Responsibility to Protect and Peace Operations]. Právo. 2008, vol. 1, issue 3, p. 13.

23 STAHN, Carsten. Responsibility to Protect: Political Rhetoric or Emerging Legal Norm? American Journal of International Law. 2007, vol. 101, issue 1, p. 111.

24 Report of the International Commission on State Sovereignty and Intervention: The Responsibility to Protect. Ottawa: International Development Research Centre, 2001, p. 48. The report provides: "Collective intervention blessed by the UN is regarded as legitimate because it is duly authorized by a representative international body; unilateral intervention is seen as illegitimate because self-interested."

25 RODLEY, Nigel. R2P and Internatinoal Law. A Paradigm Shift? In: BELLAMY, Alex, DUNNE, Tim. The Oxford Handbook of the Responsibility to Protect. Oxford: OUP, 2016, p. 191.

26 For the overview of the crisis $c f$. MOMANI, Bessma, HAKAK, Tanzeel. Syria. In: BELLAMY, Alex, DUNNE, Tim. The Oxford Handbook of the Responsibility to Protect. Oxford: OUP, 2016, pp. 895-910. 
Already in August 2013, in relation to the Syrian government's alleged use of chemical weapons, the UK government adopted and published official legal position concerning the possible use of force against Syria. It stressed that if action in the SC is blocked, the UK would still be permitted under international law to take exceptional measures in order to alleviate the scale of the overwhelming humanitarian catastrophe in Syria by deterring and disrupting the further use of chemical weapons by the Syrian regime. According to the official position, such a legal basis is available, under the doctrine of humanitarian intervention, provided three conditions are met:

(i) there is convincing evidence, generally accepted by the international community as a whole, of extreme humanitarian distress on a large scale, requiring immediate and urgent relief;

(ii) it must be objectively clear that there is no practicable alternative to the use of force if lives are to be saved; and

(iii) the proposed use of force must be necessary and proportionate to the aim of relief of humanitarian need and must be strictly limited in time and scope to this aim (i.e. the minimum necessary to achieve that end and for no other purpose). ${ }^{27}$

More or less the same legal position was adopted by Denmark in 2013. ${ }^{28}$ The UK reiterated its justification once again after the airstrikes conducted against Syria in April 2018. ${ }^{29}$

With regards to doctrine, at least some scholars consider April 2018 airstrikes to be a transformative event that has changed international law concerning humanitarian intervention. ${ }^{30} \mathrm{M}$. Scharf points out five circumstances that made the 2018 airstrikes distinctive: Syria has represented the greatest humanitarian catastrophe on the planet, airstrikes were undertaken collectively, the participating countries asserted its legality, the aim was to stop the use of chemical weapons against a civilian population (so-called narrow principle of humanitarian intervention), and finally, many states from all parts of the globe expressed sup-

27 Policy Paper, Chemical Weapon Use By Syrian Regime: UK Government Legal Position [online], 29 August 2013. Available at: https://www.gov.uk/government/publications/ chemical-weapon-use-by-syrian-regime-uk-government-legal-position/chemical-weapon-use-by-syrian-regime-uk-government-legal-position-html-version [2019-11-11].

28 General Principled Considerations on the Legal Basis for a Possible Military Operation in Syria [online]. Available at: https://www.ft.dk/samling/20121/almdel/upn/ bilag/298/1276299/index.htm [2019-11-11]. Cf. ILA Report, p. 23.

29 Policy Paper, Syria Action - UK Government Legal Position [online] 14 April 2018. Available at: https://www.gov.uk/government/publications/syria-action-uk-government-legalposition/syria-action-uk-government-legal-position [2019-11-11].

30 SCHARF, Michael. Striking a Grotian Moment: How the Syria Airstrikes Changed International Law Relating to Humanitarian Intervention Chicago Journal of International Law. 2018, vol. 19, issue 2, p. 1 . 
port, while only a handful opposed the airstrikes (Russian draft resolution condemning this airstrikes was soundly defeated by the SC). ${ }^{31}$ According to Scharf, these circumstances render this a strong case for the Grotian moment, i.e. an event that is capable to change paradigm of international relations and international law. ${ }^{32}$

\subsection{How to Assess Change of CIL on the Use of Force? Methodology of Creation} and Modification of CIL in General and Peremptory Norms (Concerning the Use of Force) in Particular

The aim of this article is to assess whether arguments raised by the UK, Denmark and the part of doctrine of international law concerning the alleged legality of humanitarian intervention and respective modification of CIL on the use of force are already valid or remain rather premature. To answer this question, the article analyzes reactions of States to the airstrikes conducted in April 2018. Before the scrutiny is conducted and final conclusions about the position of humanitarian intervention in international law are drawn, it is necessary to describe, firstly, how these reactions were identified and analyzed - to put it differently, it is inevitable to dwell on a methodology of the creation (and modification) of CIL. ${ }^{33}$

\subsubsection{Practice is the key}

At the heart of the whole debate on current stage of international law on the use of force is evaluation of practice. It was already argued that the only way in which unilateral humanitarian intervention could possibly be seen as a legal exception to the prohibition of the use of force is if State practice and opinio juris were to be found establishing its status as an additional exception in CIL. ${ }^{34}$ With respect to CIL, practice is therefore generally considered to have normgenerating effect. With respect to treaties, subsequent practice should be used in the sense of Article 31(3)(b) of the VCLT (external systematic interpretation) and should be assigned only interpretative function. ${ }^{35}$ These two conceptually

31 Ibid, pp. 27-28.

32 It is fair to say that Scharf is mindful of the risk of making too quick a judgment without the benefit of historic hindsight. Ibid, p. 28.

33 FAIX, Martin, SVAČEK, Ondřej. International Law on the Use of Force: Need for Methodological Debate. The Czech Yearbook of Public and Private International Law. 2018, vol. 9, pp. 95-110.

34 ILA Report, p. 21.

35 It might be argued that States prefer to make every effort to conceive of an agreed subsequent practice of the parties as an effort to interpret the treaty in a particular way - that is to say that evolutionary or extensive interpretation is preferred to modification of international treaty. This position is also supported by travaux préparatoires to the VCLT. Originally, the VCLT contained Draft Art 38 according to which a treaty may be modified by subsequent practice in the application of the treaty establishing the agreement of the parties to modify its provisions. Cf. ILC, A/CN.4/671, p. 52, \$119. Majority of States expressed 
similar, but separate processes take place simultaneously. State practice allowing legal argument of humanitarian intervention is therefore capable to modify existing CIL (which has until recently outlawed humanitarian intervention) and bring about extensive interpretation of the UN Charter (which - given the classicists argumentation - does not incorporate this concept either). ${ }^{36}$

With respect to Syria, three "types" of State practice were taken into consideration. Firstly, the practice of agents of the material act (e.g. the positions of the US, the UK, and France), then the practice produced during debates in the SC concerning the Russian proposal to condemn the allied airstrikes in Syria as an act of aggression, ${ }^{37}$ and finally wider practice (reactions) produced by the international community of States immediately after the military action in April $2018 .^{38}$

\subsubsection{Relevance and preference of verbal acts}

As the ILC noted, practice may take a wide range of forms. ${ }^{39}$ This includes both physical and verbal acts. Verbal acts are even more suitable examples of

objections to this provision which was later removed from the final text of the VCLT.

36 Importantly, it should be noted that in practice it is often difficult, if not impossible, to distinguish whether practice in a specific case is a proof of opinio iuris conventionalis or a confirmation of existing customary obligation (opinio juris consuetidi or sive necessitatis). As pointed out by Judge Singh, in any search to determine whether [the concept of self-defense belongs] to customary or conventional international law it would appear to be a fallacy to try to split any concept to ascertain what part or percentage of it belongs to customary law and what fraction belongs to conventional law. Nicaragua $v$. United States, Separate opinion of Judge Singh, p. 152.

37 The draft resolution - which was defeated by a recorded vote of 8 against (Côte d'Ivoire, France, Kuwait, Netherlands, Poland, Sweden, the UK, the US) to 3 in favor (Bolivia, China, Russia), with 4 abstentions (Equatorial Guinea, Ethiopia, Kazakhstan, Peru) - would have demanded the US and its allies immediately cease such actions and refrain from any further use of force in violation of international law. The failure of the SC to condemn this use of force is interpreted in compliance with the position of the ICJ. Cf. Legal Consequences for States of the Continued Presence of South Africa in Namibia (South West Africa) notwithstanding Security Council Resolution 276 (1970), Advisory Opinion, I.C.J. Reports 1971, $\$ 69$. The ICJ opined: “The fact that a particular proposal is not adopted by an international organ does not necessarily carry with it the inference that a collective pronouncement is made in a sense opposite to that proposed. There can be many reasons determining rejection or non-approval." Cf. Following Air Strikes against Suspected Chemical Weapons Sites in Syria, Security Council Rejects Proposal to Condemn Aggression. United Nations [online]. 2018-05-14 [cit. 2019-11-03]. Available at: https://www. un.org/press/en/2018/sc13296.doc.htm. Cf. Report of the 8233rd Meeting, SC, 14 April 2018, S/PV.8233.

38 A pioneer project that identified and evaluated reactions of 79 States was widely used here. Cf. DUNKELBERG, Alonso et al. Mapping States' Reactions to the Syria Strikes of April 2018 - A Comprehensive Guide. Just Security [online]. First version of 2018-05-07 [cit. 2019-11-03]. Available at: https://www.justsecurity.org/55835/mapping-states-reactionssyria-strikes-april-2018-a-comprehensive-guide/

39 ILC, Identification of Customary International Law, Conclusion 6 (ILC Report, A/71/10, 
practice than physical acts, ${ }^{40}$ because actors often express as a part of verbal acts their beliefs regarding what the law is. On the other hand, physical acts can only give an implicit indication of opinio juris - it cannot be assumed that implication of State's physical act is a belief that the act is lawful. State action as such can be illegal, but the State can nevertheless attempt to justify the conduct (action or omission) with legal arguments. To sum up, it appears that material acts, i.e. a sole conduct without any accompanying statement or any other suitable form of expression, through which the legal conviction of the State can be identified, cannot count as relevant practice.

\subsubsection{Requirement concerning formulation of a claim of a legal nature}

Verbal acts thus seem to be a more suitable source or even a necessary part accompanying the mere action in order to count as relevant practice. However here another question appears: should also verbal acts short of legal argumentation be considered as relevant? The ICJ itself made distinction between legal and extralegal (factual, moral, political) considerations and stressed that only the former are relevant, i.e. are capable of giving rise to evolution of customary international law. ${ }^{41}$ For verbal acts to be relevant they must formulate a claim of a legal nature. Only such verbal acts are related with belief in acting in accordance with international law rather than with mere courtesy, convenience, or diplomatic concerns. As pointed out by A. Orakhelashvili, "as an initial step, the position of the state that wishes to attain normative change through customary law has to be coherent and consistent so that other state can identify the parameters of the offer made." 42 To put it very simply: the straightforward official position of the UK, a public verbal pronouncement that formulates legal claim, ${ }^{43}$ represents perfect offer of this kind that really calls for reaction.

2016, chap. V, $\$ \$ 50-63)$. Cf. also ILC’s Conclusion 6 para. 2 on Subsequent agreements and subsequent practice in relation to the interpretation of treaties (ILC Report, A/71/10, 2016, chap. VI, $\$ \$ 64-76)$.

40 O'CONNELL, Mary Ellen. Taking Opinio Juris Seriously, A Classical Approach To International Law on the Use of Force. In: CANNIZZARO, Enzo, PALCHETTI, Paolo. Customary International Law on the Use of Force: Methodological Approach. Brill: Leiden, 2005, p. 15.

41 The Colombian-Peruvian Political Asylum case provides an example. The ICJ stated in its judgment several bars, which prevented in the particular case existence of a customary norm, one of them being the fact that the relevant practice of Latin American states has been extensively "influenced by considerations of political expediency". Asylum (Columbia v. Peru), Judgment, I.C.J. Reports 1950, p. 277.

42 ORAKHELASHVILI, Alexander. Changing Jus Cogens Through State Practice? In: WELLER, Marc (ed.) The Oxford Handbook of the Use of Force in International Law. Oxford: OUP, 2015, pp. 160-161.

43 Different, or rather more nuanced, position is presented by A. Kleczkowska who maintains that the UK neither claimed that there is a customary norm which would allow for a humanitarian intervention, nor that such a humanitarian intervention is permitted under the UN Charter. She concludes that the UK's argument about a humanitarian intervention was detached from any legal grounds. Cf. KLECZKOWSKA, Agata. Changing Customary 
Given that change of peremptory norm of international law is at stake, it should also be mentioned that relevance of acquiescence (as a qualified silence) is diminished; silent behavior should generate norm-evolutionary effects only under very strict conditions ${ }^{44}$ and should be admitted only with great caution. This is all the more so that there is always a thin line between mere toleration of practice and acquiescence. ${ }^{45}$

\subsubsection{Preference of inductive approach to the creation (modification) of CIL}

Doctrine and practice of international law identifies two approaches concerning the creation and modification of CIL. The first one is usually described as deductive (value-based) approach ${ }^{46}$ which is perspective. It does not look back, and is based on emerging values and interests which were considered only insufficiently in the preexisting legal balance. It does not necessarily require a consistent pattern of previous practice. This approach envisages occurrence of transformative events (the Grotian moments) which are capable to change existing legal paradigm. The second possibility is referred to as inductive (traditional) method which is based on assumption that to determine the existence and content of a rule of customary international law, it is necessary to ascertain whether there is a practice that is accepted as law (opinio juris). The latter approach is

Law. The Shape of the Prohibition of the Use of Force after the 2017 and 2018 Airstrikes in Syria. International Community Law Review. 2019, vol. 21, pp. 373-374.

44 P. Starski argues that nom-evolutionary effect can be assigned to silence only "if other states and the international community can legitimately expect that a state will make its dissenting position known", whereas existence of such expectation depends on "overall assessment of numerous factors, including: the determinacy of the legality claims made by the acting states; the capacity of silent states to act; the specific circumstances in which a claim was made; the determinacy of reactive claims of other actors; and questions of time, as well as the nature of the affected rules." Cf. STARSKI, Paulina. Silence within the process of normative change and evolution of the prohibition on the use of force: normative volatility and legislative responsibility. Journal on the Use of Force and International Law. 2017, vol. 4, issue 1, p. 14.

45 Orakhelashvili, with reference to the advisory opinion of the Permanent Court of International Justice concerning Jurisdiction of the European Commission of the Danube (cf. $\$ 93$ ), argues that toleration occurs because nothing can be physically done about the particular situation, but this is short of acceptance, which represents the confirmation of its legality. Orakhelashvili, A.: supra, p. 171.

46 CANNIZZARO, Enzo. Customary International Law on the Use of Force: Inductive Approach v. Value Oriented Approach. In: CANNIZZARO, Enzo, PALCHETTI, Paolo. Customary International Law on the Use of Force: Methodological Approach. Brill: Leiden, 2005, p. 248 
widely accepted both in the practice of the $\mathrm{ICJ}^{47}$ and the $\mathrm{ILC}^{48}$ and is therefore preferred by the present author.

\subsubsection{Irrelevance of legitimacy}

One of the crucial question concerning evaluation of State practice is, which criteria should be employed as a referential framework for assessment whether in a particular situation the use of force was permissible or not. Two major trends can be identified in international legal scholarship. ${ }^{49}$ On the one hand, scholars present extensive interpretations of the possibilities to use force, typically encompassing broad definition of self-defense (including anticipatory and preventive self-defense), a rejection of the UN monopoly to authorize military actions, and the admissibility of humanitarian intervention. These writings are generally grounded in a non-positivist approach to international law. Considerations of morality, legitimacy or politics are taken into account together with the emergence of values of democracy, rule of law, and human rights. ${ }^{50}$ This perspective might be described as a policy-oriented ${ }^{51}$ or value-oriented..$^{52}$ On the other hand, proponents of restrictive school prefer a positivist oriented method to assess use of force in international relations. Generally, these authors explicitly or implicitly argue that broadening the possibilities to use force in the name of policy considerations, morality or other values would be too dangerous, as it would open the door to arbitrariness and misuse by major powers.

Author agrees with opinion of M. E. O'Connell that reference to legitimacy always blurs the line between law and morality. ${ }^{53}$ The function of law is drawing a line between legality and illegality, any legal conclusion to be persuasive must stem from foreseeable legal argumentation and interpretation. Any reliance on meta-legal arguments undermines coherence of legal analysis. International law is not an exception therefore whether the use of force is legal should and must be found in the international legal rules. As M. Koskenniemi notes: "Key to persuasiveness is that the argument is recognizable as a good legal argument and not, for example, a strong moral point, a plausible political position, or a convincing sociological description of something". ${ }^{4}$

47 Nicaragua v. United States, $\$ 207$. The most explicit stipulation can be found in the judgment rendered in the Gulf of Maine case ( $\$ 111$ ), where the ICJ ruled that presence of customary rules "can be tested by induction based on the analysis of a sufficiently extensive and convincing practice, and not by deduction from preconceived ideas".

48 ILC, A/71/10, p. 84.

49 CORTEN, Olivier. The controversies over customary prohibition of the use of force: a methodological debate. European Journal of International Law. 2006, vol. 16, issue 5, p. 804.

50 Ibid, p. 809.

51 Ibid.

52 Cannizzaro, E.: supra, p. 248.

53 O'Connell, M. E.: supra, p. 10.

54 KOSKENNIEMI, Martti. Methodology of International Law [online]. In: The Max Planck 
With all respect and understanding to the value-oriented approach, author of the present contribution goes along with the position presented by the restrictive school. Once again, this choice has its recourse in the case-law of the ICJ. For the first time, the ICJ expressed its position clearly and unequivocally in the South West African case in $1966 .{ }^{55}$ Twenty years later, the ICJ rejected justification for intervention to Nicaragua presented by the US stressing that their "authorities have on some occasions clearly stated their grounds for intervening in the affairs of a foreign State for reasons connected with, for example, the domestic policies of that country, its ideology, the level of its armaments, or the direction of its foreign policy $[\ldots]$ but these were statements of international policy, and not an assertion of rules of existing international law." 56 To sum up, the value based approach based on arguments of morality, legitimacy or policy must be rejected unless it has sufficient expression in legal form.

\subsubsection{Assumption of changeability of peremptory norms}

That rules concerning prohibition on the use of force have peremptory character is beyond any doubt. ${ }^{57}$ Strictly speaking, a modification of this norm poses a significant legal challenge since any attempted departure from peremptory norm must be tainted with invalidity. It is then possible to argue that the

Encyclopedia of Public International Law. Available at: www.opil.ouplaw.com [2019-11-11].

55 South West Africa, Second Phase, Judgment, I.C.J. Reports 1966, p. 34, $\$ 49$. "The Court must now turn to certain questions of a wider character. Throughout this case it has been suggested, directly or indirectly, that humanitarian considerations are sufficient in themselves to generate legal rights and obligations, and that the Court can and should proceed accordingly. The Court does not think so. It is a court of law, and can take account of moral principles only in so far as these are given a sufficient expression in legal form. Law exists, it is said, to serve a social need; but precisely for that reason it can do so only through and within the limits of its own discipline. Otherwise, it is not a legal service that would be rendered."

56 Nicaragua v. United States, $\$ 207$.

57 Still, the ILC in its current work on the topic Peremptory norms of general international law (jus cogens) is speaking only about the prohibition of aggression as the most frequently cited candidate for the status of jus cogens. Cf. Report of the ILC, A/74/10, p. 208 (Annex to Draft Conclusions). If a common understanding that aggression represents only the most serious and dangerous form of the illegal use of force is adopted, the inevitable conclusion would be that the use of force short of aggression cannot be considered as a breach of jus cogens. Nevertheless, the ILC's list has only non-exhaustive character. At the same time, the case-law of the ICJ confirms that peremptory status concerns whole norm on the prohibition of the use of force. Cf. Nicaragua v. United States, $\$ 190$. “The International Law Commission, in the course of its work on the codification of the law of treaties, expressed the view that "the law of the Charter concerning the prohibition of the use of force in itself constitutes a conspicuous example of a rule in international law having the character of jus cogens" (paragraph (1) of the commentary of the Commission to Article 50 of its draft Articles on the Law of Treaties, ILC Yearbook, 1966-11, p. 247)." 
international community is confronted with perpetual jus cogens, because any attempted modifications would be nipped in the bud..$^{58}$

Such approach is nevertheless beyond international reality ${ }^{59}$ and international law itself. According to Art 53 of the VCLT, modification of a peremptory norm of general international law is likely to occur through the subsequent acceptance and recognition of a rule of customary international law as a peremptory norm of general international law or the emergence of a new rule of customary international law so accepted and recognized. However, to be able to modify a peremptory norm of general international law, the rule of customary international law in question must have the same character as the peremptory norm of general international law being modified. ${ }^{60}$

There is cogency in opinion presented by C. Mik who further elaborates on the issue of possible change of peremptory norms and concludes that "jus cogens consists of norms that cannot be changed as to their essence." 61 The creation of a new peremptory norm of an opposite content to the existing ones would presuppose the establishment of a new international community, probably a totalitarian in character. It therefore seems that a change of peremptory norms could relate only to a partial modification in the objective scope of the norm, in particular with respect to the permissibility of new exceptions (or the broadening of existing ones) from the rule expressed in such a norm. ${ }^{62}$ This is exactly the case with respect to humanitarian intervention.

Be it as it may, such a change entails a heavy burden of proof for anybody who wish to prove it. Peremptory norm is a norm of general international law that it is accepted and recognized by the international community of States as a whole as a norm from which no derogation is permitted and which can be modified only by a subsequent norm of general international law having the same character. Here, the norm-creating capacity is reserved only to the international community of States as a whole which term is interpreted by the ILC to mean a very large majority of States. ${ }^{63}$ To employ argument a minori ad maius, if the creation of

58 The ILC refers to the High Court of Kenya, in The Kenya Section of the International Commission of Jurists $v$. the Attorney-General and Others, which stated that peremptory norms of general international law (jus cogens) rendered void any other [peremptory] rules which come into conflict with them. $C f$. ILC, A/74/10, p. 183.

59 DÖRR, Oliver, SCHMALENBACH, Kirsten. The Vienna Convention on the Law of Treaties. A Commentary. Springer, 2012, p. 917.

60 ILC, A/74/10, p. 183.

61 MIK, Cezary. Jus Cogens in Contemporary International Law. Polish Yearbook of International Law. 2013, vol. 33, p. 43.

62 Ibid.

$63 C f$. Draft Conclusion 7(2). ILC, A/74/10, p. 168. “The Commission considered that acceptance and recognition by a simple "majority" of States was not sufficient to establish the peremptory status of a norm. Rather, the majority had to be very large. Determining whether there was a very large majority of States accepting and recognizing the peremptory status of a norm was not, however, a mechanical exercise in which the number of States is to be 
a new rule of "mere" general (in the sense of non-peremptory) CIL is precluded where the international community of States is divided on the particular issue, the same conclusion must be steadfastly applied also with respect to the creation (modification) of peremptory norm of general international law. ${ }^{64}$

It he light of all the foregoing considerations, it would be necessary, in the context of creation of jus cogens, to show that there is a general and consistent practice of a very large majority of States, from which a certain rule of conduct emerges, coupled with a belief that such a rule is binding and of a peremptory character (so-called double opinio juris).

\subsection{Assessment of State Reactions to the Syria Strikes of April 2018}

\subsubsection{Position of the UK, the US, and France}

The position of the UK was already cited.$^{65}$ It should be stressed once again that this statement concerns formulation of a clear legal claim (even if it does not specify neither its legal source nor the way it was created). The UK invokes its permission (and corresponding permission of any other State) ${ }^{66}$ under international law to take measures in order to alleviate overwhelming humanitarian suffering and refers to the concept of humanitarian intervention as the legal basis of its act. This is definitively a very good starting point.

As to France, its statement (presented before the UN SC) is less explicit with respect to justification of the use of force in Syria. Nevertheless, it might be still classified as a supportive position bolstered by reference to international law. France opined that its "action was in full conformity with the objectives and values enshrined in the UN Charter, from its very first lines [...] the Charter was not designed to protect criminals, and France's action was in line with its goals and values." At the same time, argument raised by France reminds logic of countermeasures ("this action was indeed necessary in order to address the repeated vio-

counted. The acceptance and recognition by the international community of States as a whole requires that the acceptance and recognition be across regions, legal systems and cultures. The view was expressed that in the light of importance of State consent and the extraordinarily strong legal effect of peremptory norms of general international law (jus cogens), the recognition and acceptance of the "overwhelming majority of States", "virtually all States", "substantially all States" or "the entire international community of States as a whole" was required."

64 Legality of the Threat or Use of Nuclear Weapons, Advisory Opinion, I.C.J. Reports 1996, $₫$ 73. "[Despite] desire of a very large section of the international community to take, by a specific and express prohibition of the use of nuclear weapons, a significant step forward along the road to complete nuclear disarmament [...] The emergence, as lex lata, of a customary rule specifically prohibiting the use of nuclear weapons as such is hampered by the continuing tensions between the nascent opinio juris on the one hand, and the still strong adherence to the practice of deterrence on the other."

$65 C f$. footnotes 27 and 29.

66 S/PV.8233, pp. 6-7. 
lations by the Syrian regime of its obligations") what is nevertheless problematic due to a well-established prohibition of armed countermeasures (reprisals). ${ }^{67}$ President Macron stated that the attack was targeted against the capacities of the Syrian regime which allow it to produce and employ chemical weapons. ${ }^{68}$

The position of the US was nevertheless much less straightforward. During discussion before the SC, Nikki Haley, the US Permanent Representative to the $\mathrm{UN}$, delivered a statement which contains international law aspects, however, it avoids raising any type of legal justification for the allied action under international law on the use force. ${ }^{69}$ The relevance of this claim is therefore very limited. Statement by President Trump does not contain any reference to international law at all; it uses rather political rhetoric and stresses that "the purpose of our actions tonight is to establish a strong deterrent against the production, spread, and use of chemical weapons." ${ }^{\prime \prime}$

Based on criteria described and analyzed in the previous part, it is possible to draw a partial conclusion that clear and relevant justification of the airstrikes based on jus ad bellum argumentation was presented only by the UK and France.

\subsubsection{Discussion before the UN SC}

More reactions can be found in discussion before the SC. Unsurprisingly, strong language of condemnation was used by Russia, convener of the emergency meeting of the SC. Its representative referred to a statement of President Putin, who described the airstrikes in following words: "An act of aggression against a sovereign State on the front lines in the fight against terrorism was committed without permission from the Security Council and in violation of the Charter of the United Nations and the norms and principles of international law." ${ }^{1}$ Russia strong condemnation was replicated by Bolivia, which stated that "three

67 Cf. Art 50(1)(a) of the Draft Articles on Responsibility of States for Internationally Wrongful Acts (2001).

68 Kleczkowska, A.: supra, p. 373.

69 Hereafter, in this section, all statements and reactions will not be referred to separately. They all are available at: https://www.justsecurity.org/55835/mapping-states-reactionssyria-strikes-april-2018-a-comprehensive-guide/ [11-11-2019].

70 Statement by President Trump on Syria. White House [online]. 2018-09-13 [cit. 2019-1105]. Available at: https://www.whitehouse.gov/briefings-statements/statement-presidenttrump-syria/. The international legal argumentation is missing even in the Memorandum opinion adopted by the US Department of Justice (the Office of Legal Counsel) in May 2018 which came to conclusion that "the President could lawfully direct airstrikes on facilities associated with Syria's chemical-weapons capability because he had reasonably determined that the use of force would be in the national interest." The referential legal framework, upon which the legality of the use of force was evaluated and tested in this memorandum, was only the US legal order. The memorandum concluded that there had been no need for the President to obtain congressional authorization before the airstrikes were directed.

71 S/PV.8233, p. 3. 
permanent members have made the decision, in violation of the Charter of the United Nations, to take unilateral action against the sovereignty and territorial integrity of another State Member of the Organization." ${ }^{\prime 2}$

More diplomatic expressions, but clearly of legally rejective character, were used by China, which stressed that any unilateral military actions that circumvent the SC contravene the purposes and principles of the UN Charter. The same position was presented by Equatorial Guinea and Kazakhstan.

A softer language, nevertheless still the one that tends to unlawfulness of the strikes, were used by Kuwait, which reiterated adherence to the principles of non-use or threat of force and peaceful dispute settlement, and Côte d'Ivoire, which stressed that the use of force must be authorized by the SC in order to endow these actions with the essential legal authority and avoid any abuses.

With respect to Sweden, which stressed primary responsibility of the SC, of importance is its explanation following a vote on draft resolution: "We agree with the Secretary-General that there is an obligation that actions be consistent with the Charter of the UN and with international law in general." Very similar statement was produces by Peru, which stressed that "any response to crimes committed in Syria, or a solution to them, must be in line with the Charter." It might be argued that by implication, Sweden and Peru considered the allied strikes in Syria illegal.

On the other side, Poland expressed its support to the action, because in the light of repeated chemical weapons attack, the international community cannot remain passive. Unfortunately, Poland did not raise any legal justification for the use of force.

The Netherlands and Ethiopia focused more on accountability for the use of chemical weapons and did not put forward any comments concerning jus ad bellum.

What conclusions to infer from this brief overview of discussion before the SC? The first obvious inference is that negative voices pointing to unlawfulness of the airstrikes prevail, even if the spectrum of opinions varies from clear illegality to illegality by implication. The only one State which openly expressed its support to the allies' action was Poland, but without raise of any jus ad bellum argumentation that would substantiate its position. Secondly, in line with the position introduced in the previous text, it is not possible to overestimate the fact that the draft resolution condemning the action was soundly rejected, as the reasons for its defeat might be totally unrelated to possible legal qualification of this action. This is perfectly visible on the example of Ethiopia, which explained its abstention from voting by pragmatic grounds, stressing that even if the draft had received 9 votes, it would have been vetoed and held only symbolic value.

72 Ibid, p. 14. 


\subsubsection{Reactions of the international community (of States)}

Responses of the international community of States might be (for a better clarity) divided into four groups: condemnation with reference to international law, condemnation without reference to international law, support without reference to international law, and finally neutral position (e.g. position which cannot be interpreted either as supportive or rejective).

An illustrative proponent of the first group is South Africa which stated that "the alleged use of chemical weapons in Syria cannot be a justification for military airstrikes in a territory of a sovereign state without the authorisation of the UNSC. In the same vein, South Africa condemns the use of chemical weapons by any party in the Syrian territory." Similar position was presented by Austria, Costa Rica, Cuba, Iran, Lebanon, Namibia, Venezuela, and (obviously) Syria. Brazil, Indonesia, Malaysia, Pakistan, Thailand, Uruguay, and Vietnam, without explicit condemnation, accentuated the need for all parties concerned to comply with international law, in particular the UN Charter. For example Pakistan explained that its "position on the situation in Syria is based on the principles of international law, the UN Charter and the rules of inter-state conduct with special focus on respect for the sovereignty and territorial integrity of Syria." Even if these last 7 countries did not condemn the action expressly, their reactions are obviously neither supportive nor neutral (the reference to the UN Charter is not meaningless), it is reasonable to conclude that they rejected legality of the action at least implicitly. ${ }^{73}$

Secondly, some States expressed disapproval of the airstrikes without a statement concerning their illegality. According to Tunisia, "military intervention in Syria has worsened the already destabilized situation in the country [...] a solution can only be reached through political means." Similar positions were taken by Algeria, Egypt, Morocco, Sudan, and Switzerland.

As a "mouthpiece" of the third group, the statement of the Czech Republic might be quoted here: "The Czech Republic understands the US and allies' military action as a clear message to anyone, who would want to carry on with the chemical attacks in Syria. The UN Security Council has not been able to take effective measures to resolve the situation." Mostly, as it is seen in this example, States usually pointed out to the fact of the massive use of chemical weapons against civilian population (sometime stressing illegality of such conduct - cf. Albania, Finland, or Ukraine), but did not formulate legal argument concerning jus ad bellum. Very often these statements are blurred with extra-legal invocations (e.g. action was justified, legitimate, proper or adequate). Bulgaria, despite expression of support, believed that the action was " $a$ one-time limited blow", therefore

73 The official position of the African Union would be of a similar character: "The African Union, which is strongly committed to multilateralism, underlines that any response to such acts ought to be based on incontrovertible evidence gathered by a competent, independent and credible entity and comply strictly with international law, including the primacy of the United Nations Security Council for any recourse to force." 
stripping it of any potential precedential value. Some 34 States might be included in this group: Albania, Australia, Bahrain, Belgium, Bulgaria, Canada, Colombia, Croatia, Czech Republic, Denmark, Estonia, Finland, Georgia, Germany, Greece, Ireland, Israel, Italy, Japan, Jordan, Lithuania, Macedonia, New Zealand, Norway, Oman, Qatar, Romania, Saint Lucia, Saudi Arabia, South Korea, Spain, Turkey, Ukraine, and the United Arab Emirates. ${ }^{74}$

The last group concerns States that took a neutral stance. The best example here would be a statement of Panama, which "called upon the great powers to seek paths that allow the Syrian people to achieve lasting peace." These kinds of statements can hardly contribute to the development of CIL in the area of jus ad bellum. This group is comprised further of Argentina, Chile, Guatemala, India, Iraq, Mexico, and Philippines.

Interestingly, there was no single response identified that would express support for the action with formulation of a clear international legal claim.

\subsubsection{Overall evaluation}

It was already explained that any modification of the international legal framework concerning the prohibition on the use of force, as a pioneering category of juris cogentis, requires not only support of very significant number of States, but also very significant quality of their statements. The overview of State practice, that includes positions of 79 States, is therefore self-explanatory: neither quantitative nor qualitative requirement concerning the modification of peremptory norms of international law has been met. Moreover, the practice is markedly divided what makes the formation and modification of general CIL, and all the more so rule of a peremptory character, hardly possible. There are only two States (even if the P5 members) who were ready to justify the airstrikes with the reference to international law. It is obvious that the creation of a permissive rule marking the exception to the prohibition on the use of force requires dramatically larger flock of swallows. The imaginary gauntlet thrown by the UK (and France) has not been adequately picked up. On the other hand, 24 reactions (including two of the P5 members) reveal denunciation of the bombardment, even if positions vary considerable and include claims both of explicit and implicit unlawfulness. The numerous group of 35 States that expressed their support in politically formulated proclamations, short of any legal argumentation concerning jus ad bellum, might confer the allied campaign certain legitimacy, what is nevertheless of zero relevance from the perspective of the formation and modification of CIL.

74 The official position of NATO would fit into this category: "Allies expressed their full support for this action intended to degrade the Syrian regime's chemical weapons capability and deter further chemical weapon attacks against the people of Syria." 


\section{Conclusion}

The inevitable conclusion which can be drawn from the foregoing analysis is that a new possible exception of humanitarian intervention to the general prohibition on the use of force has not yet been established, materialized or crystallized. The concept of humanitarian intervention therefore still remains beyond the scope of the current international legal framework. At the same time, it can be said that the process of creation of this exception has already been triggered, although it is to be found only in a very initial phase. The position of the UK, which formulates clear claim of a legal nature, is a starting point to which other members of the international community can aim their reactions. Even if the opinion positing the lawfulness of humanitarian intervention is still marginal and miles distant from satisfying the required criterion of the acceptance and recognition by the international community of States as a whole, one cannot rule out the possibility of gradual growth in numbers of States that will join the group of supporters. It is likely that more and more States will express their legal claim arguing in favor of humanitarian intervention (as a part of hard law), or that there will be increase in number of responses that will proclaim political support to this kind of military actions (these political statements, short of any legal claim, might be considered to be a sort of soft law that will set a stage for presentation of a clear legal argument).

Still, if a divide in opinions of the international community of States is sustained, the creation of any exception to the prohibition on the use of force based on humanitarian grounds is unlikely, if not impossible. In the opinion of this author, the change of existing paradigm is conceivable only in reaction to a particularly extreme situation of serious violations of human rights that would unify very large majority of States in a conviction that a forcible reaction is not only permissible but also necessary. What is troubling here (given the international reality) is the fact that even the cataclysmic situation in Syria did not satisfy this threshold. Last but not least, one should not forget the existence and availability of the collective security system. Once the P5 are unanimous (in the light of the potential situation of extreme and flagrant violations of human rights) the collective action will obviously get precedence over any unilateral response. This simple fact downgrades the possibility of crystallization of the rule concerning unilateral humanitarian intervention.

\section{References}

BARINKA, Roman. Status humanitární intervence v mezinárodním právu. [Status of Humanitarian Intervention in International Law]. Právník. 2003, vol. 142, issue 9, pp. 855-900.

BROWNLIE, Ian. "International Law and the Use of Force by States" Revisited. Europaeum, 2001. $37 p$.

CANNIZZARO, Enzo. Customary International Law on the Use of Force: Inductive 
Approach v. Value Oriented Approach. In: CANNIZZARO, Enzo, PALCHETTI, Paolo. Customary International Law on the Use of Force: Methodological Approach. Brill: Leiden, 2005, pp. 245-268.

CASSESE, Antonio. A Follow - Up: A Forcible Humanitarian Countermeasures and Opinio Necessitatis. European Journal of International Law. 1999, vol. 10, issue 4, pp. 791-799.

CORTEN, Olivier. The controversies over customary prohibition of the use of force: a methodological debate. European Journal of International Law. 2006, vol. 16, issue 5, pp. 803-822.

DE HOOGH, André. Jus Cogens and the Use of Armed Force. In: WELLER, Marc (ed.) The Oxford Handbook of the Use of Force in International Law. Oxford: OUP, 2015, pp. 1161-1186.

Declaration on Inadmissibility of Intervention in the Domestic Affairs of States and Protection of Their Independence and Sovereignty. G. A. Res. 2131, U. N. Doc. A/6014 (1965).

Declaration on Principles of International Law Concerning Friendly Relations and Cooperation among States in accordance with the Charter of the United Nations. G. A. Res. 2625, U. N. Doc. A/8028 (1970).

DÖRR, Oliver, SCHMALENBACH, Kirsten. The Vienna Convention on the Law of Treaties. A Commentary. Springer, 2012. 1412 p.

DUNKELBERG, Alonso et al. Mapping States' Reactions to the Syria Strikes of April 2018 - A Comprehensive Guide. Just Security [online]. First version of 2018-05-07. Available at: https://www.justsecurity.org/55835/mapping-states-reactions-syria-strikesapril-2018-a-comprehensive-guide/

FAIX, Martin, SVAČEK, Ondřej. International Law on the Use of Force: Need for Methodological Debate. The Czech Yearbook of Public and Private International Law. 2018, vol. 9, pp. 95-110.

Following Air Strikes against Suspected Chemical Weapons Sites in Syria, Security Council Rejects Proposal to Condemn Aggression. United Nations [online]. 2018-05-14. Available at: https://www.un.org/press/en/2018/sc13296.doc.htm.

FRANCK, Thomas. Interpretation and Change in the Law of Humanitarian Intervention. In: HOLZGREFE, J. L., KEOHANE, Robert (Eds.) Humanitarian Intervention: Ethical, Legal and Political Dilemmas. Cambridge, CUP 2003, pp. 204-231.

General Principled Considerations on the Legal Basis for a Possible Military Operation in Syria [online]. Available at:

GOWLLAND-DEBBAS, Vera. The Limits of Unilateral Enforcement of Community Objectives in the Framework of UN Peace Maintenance. European Journal of International Law. 2000, vol. 11, issue 2, pp. 361-383.

HEIECK, John. A Duty to Prevent Genocide. Due Diligence Obligations among the P5. Edward Elgar, 2018. 264 p.

ICJ, Asylum (Columbia v. Peru), Judgment, I.C.J. Reports 1950.

ICJ, Legal Consequences for States of the Continued Presence of South Africa in Namibia (South West Africa) notwithstanding Security Council Resolution 276 (1970), Advisory Opinion, I.C.J. Reports 1971.

ICJ, Legality of the Threat or Use of Nuclear Weapons, Advisory Opinion, I.C.J. Reports 1996.

ICJ, Legality of Use of Force (Serbia and Montenegro v Belgium), Oral Proceedings, Public Sitting (12 May 1999). 
ICJ, Military and Paramilitary Activities in and against Nicaragua (Nicaragua v. United States of America). Merits, Judgment. I.C.J. Reports 1986 (including Separate opinion of Judge Singh).

ICJ, South West Africa, Second Phase, Judgment, I.C.J. Reports 1966.

ILA, Final Report on Aggression and the Use of Force, 2018.

ILC, Identification of Customary International Law, ILC Report, A/71/10, 2016.

ILC, Subsequent agreements and subsequent practice in relation to the interpretation of treaties, ILC Report, A/71/10, 2016.

KLECZKOWSKA, Agata. Changing Customary Law. The Shape of the Prohibition of the Use of Force after the 2017 and 2018 Airstrikes in Syria. International Community Law Review. 2019, vol. 21, pp. 369-389.

KOSKENNIEMI, Martti. Methodology of International Law [online]. In: The Max Planck Encyclopedia of Public International Law. Available at: www.opil.ouplaw.com

LINDERFALK, Ulf. The Effect of Jus Cogens Norms: Whoever Opened Pandora's Box, Did You Ever Think About the Consequences? European Journal of International Law. 2008, vol. 18, issue 5, pp. 853-871.

MIK, Cezary. Jus Cogens in Contemporary International Law. Polish Yearbook of International Law. 2013, vol. 33, pp. 27-93.

MOMANI, Bessma, HAKAK, Tanzeel. Syria. In: BELLAMY, Alex, DUNNE, Tim. The Oxford Handbook of the Responsibility to Protect. Oxford: OUP, 2016, pp. 895-910.

O'CONNELL, Mary Ellen. Taking Opinio Juris Seriously, A Classical Approach To International Law on the Use of Force. In: CANNIZZARO, Enzo, PALCHETTI, Paolo. Customary International Law on the Use of Force: Methodological Approach. Brill: Leiden, 2005, pp. 9-30.

ORAKHELASHVILI, Alexander. Changing Jus Cogens Through State Practice? In: WELLER, Marc (ed.) The Oxford Handbook of the Use of Force in International Law. Oxford: OUP, 2015, pp. 157-175.

Policy Paper, Chemical Weapon Use By Syrian Regime: UK Government Legal Position [online], 29 August 2013. Available at:

Policy Paper, Syria Action - UK Government Legal Position [online] 14 April 2018. Available at: https://www.gov.uk/government/publications/syria-action-uk-governmentlegal-position/syria-action-uk-government-legal-position

Report of the International Commission on State Sovereignty and Intervention: The Responsibility to Protect. Ottawa: International Development Research Centre, 2001.

RODLEY, Nigel. R2P and Internatinoal Law. A Paradigm Shift? In: BELLAMY, Alex, DUNNE, Tim. The Oxford Handbook of the Responsibility to Protect. Oxford: OUP, 2016, pp. 186-207.

SCHARF, Michael. Striking a Grotian Moment: How the Syria Airstrikes Changed International Law Relating to Humanitarian Intervention Chicago Journal of International Law. 2018, vol. 19, issue 2, pp. 1-29.

SIMMA, Bruno. NATO, the UN and the Use of Force: Legal Aspects. European Journal of International Law. 1999, vol. 10, issue 1, pp. 1-22.

STAHN, Carsten. Responsibility to Protect: Political Rhetoric or Emerging Legal Norm? American Journal of International Law. 2007, vol. 101, issue 1, pp. 99-120.

STARSKI, Paulina. Silence within the process of normative change and evolution of the prohibition on the use of force: normative volatility and legislative responsibility. Journal on the Use of Force and International Law. 2017, vol. 4, issue 1, pp. 14-65. 
ICLR, 2019, Vol. 19, No. 2.

Statement by President Trump on Syria. White House [online]. 2018-09-13. Available at: https://www.whitehouse.gov/briefings-statements/statement-president-trump-syria/

SVAČEK, Ondřej. Dárfúr - přes humanitární intervenci $\mathrm{k}$ odpovědnosti chránit a mírovým operacím. [Darfur - From Humanitarian Intervention to Responsibility to Protect and Peace Operations]. Právo. 2008, vol. 1, issue 3, pp. 5-18.

VÁLEK, Petr. Is Unilateral Humanitarian Intervention Compatible with the UN Charter? Michigan Journal of International Law. 2005, vol. 26, issue 4, pp. 1223-1255.

VENTURA, Manuel. The Prevention of Genocide as a Jus Cogens Norm? A Formula for Lawful Humanitarian Intervention. In: JALLOH, Charles, OLUFEMI, Elias (eds.) Shielding Humanity: Essays in International Law in Honour of Judge Abdul G. Koroma. Boston/Leiden, Martinus Nijhoff Publishers, 2015, pp. 289-351. 